\title{
Hydrostructural setting of Riardo Plain: effects on Ferrarelle mineral water type
}

\section{Assetto idrostrutturale della piana di Riardo: influenza sulle caratteristiche dell'acqua minerale Ferrarelle}

\author{
Stefano Viaroli, Lucia Mastrorillo, Roberto Mazza, Vittorio Paolucci
}

\begin{abstract}
Riassunto: Lo sfruttamento delle risorse idriche sotterranee deve sempre tenere conto dell'assetto geologico e idrogeologico del bacino di alimentazione per il corretto dimensionamento dei prelievi, in modo da non sovrasfruttare l'acquifero. Soprattutto nel caso dello sfruttamento di acque minerali, va aggiunta maggiore accortezza al fine di capire anche quelli che sono i meccanismi d'interazione acqua-roccia-gas che permettono di ottenere una specifica acqua. Il caso dell'acqua minerale Ferrarelle (settore occidentale della Piana di Riardo, Caserta) è particolarmente complesso. Tramite l'acquisizione d'ingenti quantità di materiale bibliografico e tramite nuove campagne idrogeologiche è stato possibile dettagliare i livelli acquiferi presenti, distinguendo quattro circolazioni tra il Roccamonfina e la Piana di Riardo. La presenza delle coperture vulcaniche e vulcanoclastiche del Vulcano di Roccamonfina sopra un substrato carbonatico fortemente tettonizzato permette la formazione di due acquiferi in continuità idraulica. Questo mixing tra i due acquiferi permette, insieme alla risalita di $\mathrm{CO}_{2}$ profonda attraverso faglie nel substrato carbonatico, la formazione del tipico chimismo dell'acqua minerale Ferrarelle. Nel settore orientale della stessa piana invece, si riescono a distinguere l'acquifero vulcanico da quello carbonatico probabilmente per la presenza di depositi a bassa permeabilità.
\end{abstract}

Parole chiave: acquifero vulcanico, acquifero carbonatico, flusso delle acque sotterranee.

Keywords: volcanic aquifer, carbonate aquifer, groundwater flow.

Stefano VIAROLI 奉"=

Sciences Department, Roma Tre University

Largo San Leonardo Murialdo 1, 00146 Rome, Italy.

E-mail: stefano.viaroli@uniroma3.it

Lucia MASTRORILLO, Roberto MAZZA

Sciences Department, Roma Tre University

Vittorio PAOLUCCI

Ferrarelle S.p.A., Riardo (CE), Italy

Ricevuto: 18 luglio 2016 / Accettato: 24 settembre 2016 Pubblicato online: 3 ottobre 2016

This is an open access article under the CC BY-NC-ND license: http://creativecommons.org/licenses/by-nc-nd/4.0/

(C) Associazione Acque Sotterranee 2016
Abstract: The exploitation of groundwater resources must always keep in account the geology and hydrogeological settings of the catchment basin for the sustainability of withdrawals, in order not to overexploit the aquifer. Especially, in the case of mineral water extraction, even more attention should be paid to understand what are the water-rock-gases interaction mechanisms, which allow obtaining a specific water chemistry. The case of Ferrarelle mineral water (western sector of Riardo Plain, Caserta) is particularly complex. Through the acquisition of a great amount of former geological and hydrogeological data and by new bydrogeological surveys, it has been possible to distinguish the aquifer levels, distinguishing four circulations over the Roccamonfina Volcano and in the Riardo Plain. The presence of volcanic and volcaniclastic deposits deriving from the Roccamonfina Volcano which cover a highlytectonized carbonate bedrock, allows the formation of two aquifers in bydraulic continuity. This mixing between the two aquifers allows, with the ascent of deep $\mathrm{CO}_{2}$ through faults in the carbonate bedrock, the formation of the typical chemical composition of the mineral water Ferrarelle. In the eastern sector of the plain, it is possible to distinguish the volcanic aquifer from the carbonate one, probably due to the presence of low permeability deposits.

\section{Introduction}

Groundwater resource management requires a thorough knowledge of the aquifer in order to ensure the sustainability of the exploitation. All main hydrogeological features (recharge, aquifer geometry and groundwater flow directions) must be identified before planning the groundwater use and its long-term impact must be evaluated with a great degree of accuracy (Sahuquillo 1985).

In mineral water exploitation, the knowledge of aquifer system must be even more detailed, in order to guarantee the protection of the groundwater resource from contamination and to respect the original water chemical composition, as indicated on the bottle label, in compliance with European (2009/54/CE) and Italian laws (Dlgs 08/10/2011 n 176 and subsequent modifications and additions). The planning of mineral groundwater exploitation needs specific investigations about the mineralization processes. The chemical composition of mineral waters is mainly determined by the water-rock interaction, but it also highly depends on the availability of the factors enhancing mineralization, such as temperature, $\mathrm{CO}_{2}$ concentration and redox conditions (Zuurdeeg and van der Weiden 1985, Van der Aa 2003).

Ferrarelle is one of the most famous brand of naturally sparkling mineral water in the world. Its pumping and bottling plant is located in the Riardo Plain, about $100 \mathrm{~km}$ 
north of Naples. In this basin, volcanic and volcanoclastic deposits cover a limestone basement. Natural presence of $\mathrm{CO}_{2}$ and relatively low $\mathrm{pH}$ values favored the intense water-rock interaction with dissolution of limestone rocks (Bono and Boni 2001, Cuoco et al. 2010). Nevertheless, the groundwater enrichment in chemical elements derived from the volcanic rocks leaching, points out the mixing between different aquifers (Dinelli et al. 2010).

Such a complex sparkling groundwater system needs to be investigated using a multidisciplinary approach, in order to identify the local geological and hydrogelogical settings for the description of the geochemical processes. Geological and geophysical investigations, pumping tests, long time groundwater level monitoring, hydrogeochemical, isotopic data and numerical modelling provided complementary information on the geometry, hydrodynamic characteristics and functioning of this mineral system (Maréchal et al. 2013). In order to progressively improve the knowledge about the exploited mineral aquifer, Ferrarelle S.p.a. works together with several Italian Research Teams since the 90's (Imperato et al. 2016, Cuoco et al. 2016, Mazza et al. 2016, Sacchi et al. 2016).

In 1998, a scientific collaboration between Ferrarelle S.p.a. and the Science Department of Roma Tre University started, with the aim of defining the hydrogeological settings of the Riardo Plain aquifers. The results shown in this paper give a scientific contribute to a better understanding of the relationship between the geological settings and the aquifers geometry, which determines the famous peculiar chemical quality of the brand's water. The analysis of the groundwater table elevation, the discrimination of different deep flow circulations and the comparison between them and the water chemistry, form the topics of this article. The result achieved

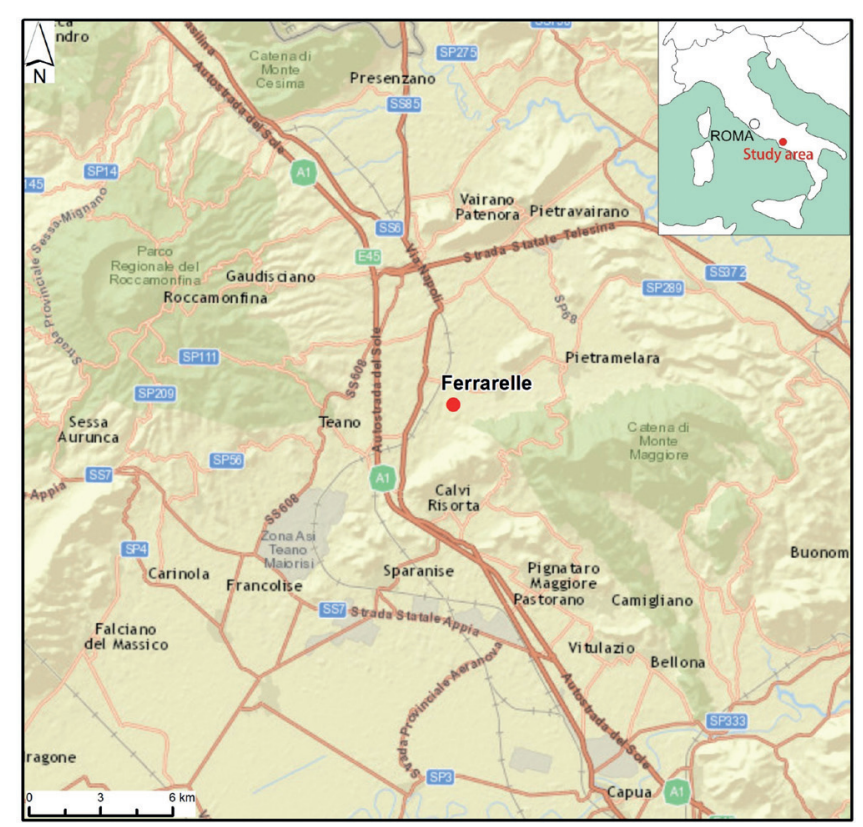

Fig. 1 - Geographical localization of the study area; the red dot corresponds to the Ferrarelle S.p.a. plant.

Fig. 1 - Localizzazione geografica dell'area di studio; il puntino rosso corrisponde allo stabilimento Ferrarelle S.p.a. seems to be appropriate to improve the multidisciplinary knowledge framework, required by the Ferrarelle water resource management.

\section{Geological setting}

The aquifer exploited by Ferrarelle s.p.a is hosted under the Riardo Plain, an intra-Apennine basin located in North Campania Region (Fig. 1).

Reliefs of different nature enclose the plain. Carbonate chains (South Apennines) enclose the plain on all edges, except to the west, where Roccamonfina Volcano grew up. The hydrographic watershed between the Volturno River and the Savone River basins is located in the middle of the plain (Fig. 2). The original Ferrarelle springs, now replaced by a well field, fed the Savone River with an undefined discharge, probably about one hundred liters per second (Imperato unpublished report 2010).

The geological setting of the study area was realized by summarizing the main results of former researches (Servizio Geologico d'Italia 1966, 1971, Celico et al. 1977, 1983, Capuano et al. 1992, Giordano et al. 1995, Civitelli and Brandano 2005) and the detailed information from several unpublished technical reports (Mazza et al. unpublished report 2014; Università degli Studi di Roma Tre, unpublished report 1996, 1997; Parotto and Funiciello unpublished report 1993).

The carbonate Southern Apennines are made up mainly by the shelf limestone succession with a thickness of about $1500 \mathrm{~m}$, deposited from lower Lias to Upper Cretaceous (D’Argenio and Pescatore 1962). This sedimentary succession was affected by two distinct deformational events. The first compressive tectonic stage (Messinian to early lower Pliocene) caused the tectonic overlap of the carbonate units. The subsequent extensional tectonic stage (lower Pliocene-upper Pleistocene) triggered the beginning of the volcanic activity of Roccamonfina center and it produced a horst and graben structure extended with NW-SE direction and dislocated with NE-SW direction (Chiappini et al. 1998). The dislocation of the sedimentary basement formed the tectonic basin of Riardo Plain, subsequently filled by volcanic, volcanoclastic and alluvial deposits.

The extensional tectonic system allows gas vents (mostly $\mathrm{CO}_{2}$ ) upraise. The fractures and the extensional faults constitute the preferential tracks for the mixing between the deep-seated fluids with the groundwater, producing the mineral waters.

The carbonate structure of the Mount Maggiore ridge highlights the presence of a NW-SE horst, bounded to the west by the Rocchetta normal Fault (Giordano et al. 1995) whose vertical displacement exceeds $1000 \mathrm{~m}$, laterally posing the Triassic dolomitic limestone and the miocenic flysch deposits (D'Argenio and Pescatore 1963) (Fig. 3). Therefore, in the inner of the relief, the dolomite and dolomitic limestone (Upper Trias-Lower Jurassic) represent the oldest outcropping carbonate unit, at an elevation of about $500 \mathrm{~m}$ a.s.l. The longitudinal extension of this horst is gradually lowered toward north by NE-SW normal faults. 


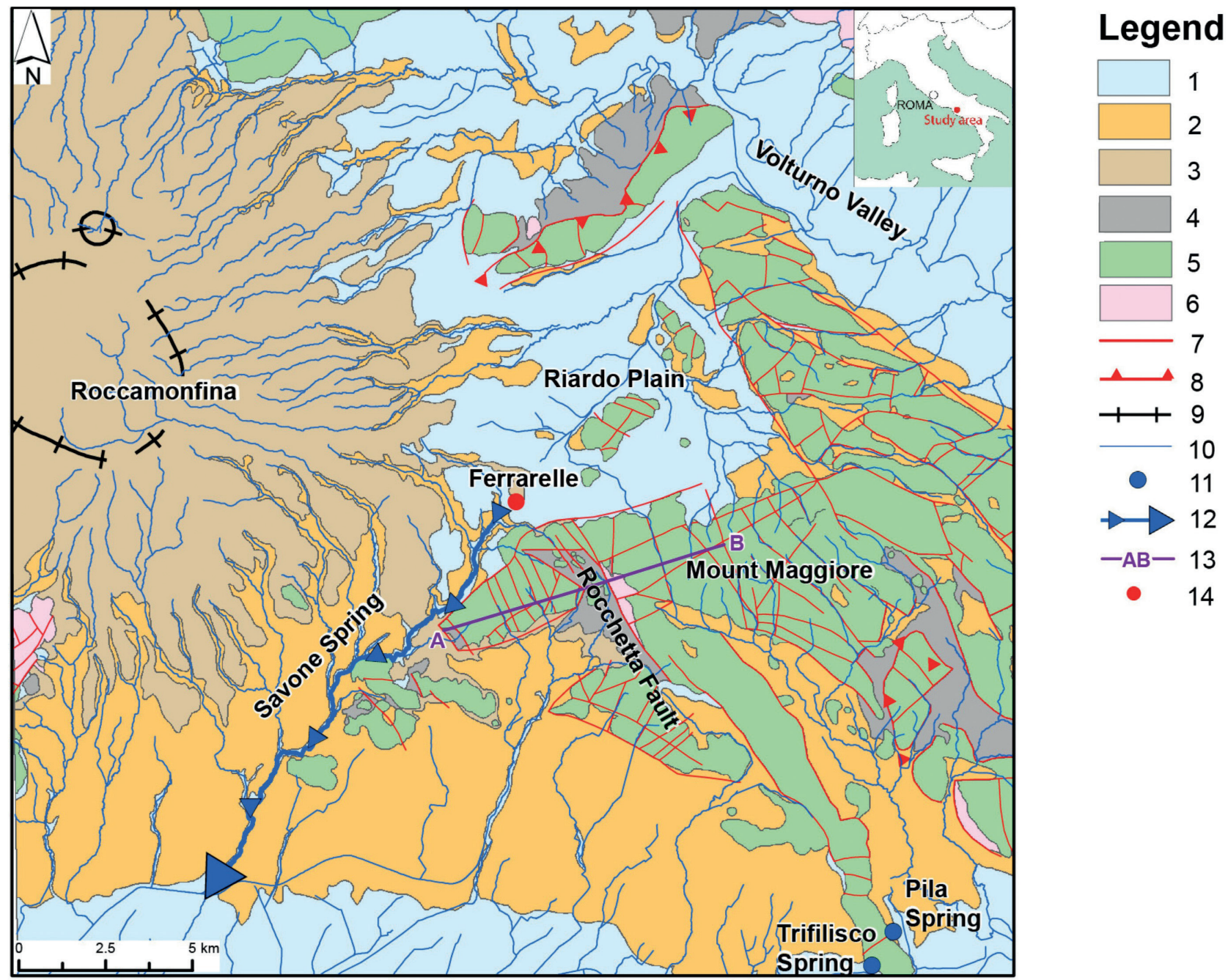

Fig. 2 - Geological map of the study area (modified from Servizio Geologico d'Italia 1966, 1971). Hydrogeological information from Boni et al. (1986). Legend: 1) alluvial deposits; 2) Campanian ignimbrite; 3) Roccamonfina volcanic deposits; 4) fysch units; 5) limestone; 6) Dolomitic limestone; 7) faults; 8) thrust; 9) caldera rim; 10) bydrographic pattern; 11) main localized springs; 12) Savone River linear spring; 13) trace of geological cross section; 14) Ferrarelle S.p.a. plant.

Fig. 2 - Carta geologica dell'area di studio (modificata da Servizio Geologico d'Italia 1966, 1971). Le informazioni di natura idrogeologica da Boni et al. (1986). Legenda: 1) depositi alluvionali; 2) ignimbrite campana, 3) depositi vulcanici del Roccamonfina; 4) unità flyschoidi; 5) calcari; 6) calcari dolomitici; 7) faglie; 8) sovrascorrimenti; 9) orlo calderico; 10) reticolo idrografico; 11) principali sorgenti puntuali; 12) sorgente lineare del Fiume Savone; 13) traccia del profilo geologico; 14) stabilimento Ferrarelle S.p.a..

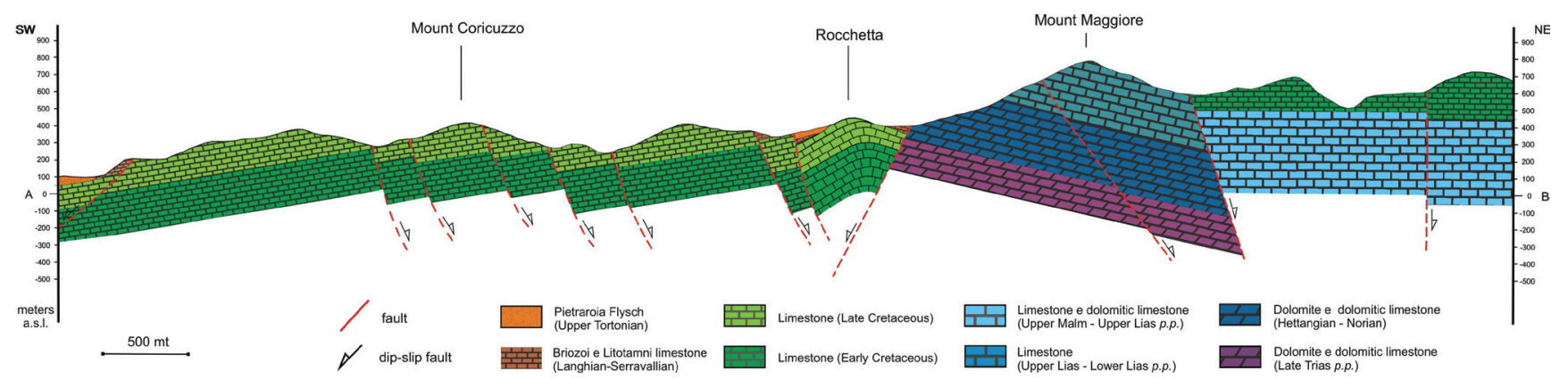

Fig. 3 - Geological cross section of the Mount Maggiore ridge (Mazza et al. 2013). The trace of the geological cross section is reported in Fig. 2.

Fig. 3 - Profilo geologico della dorsale di Monte Maggiore (Mazza et al. 2013). La traccia del profilo è riportata in Fig. 2. 
The Roccamonfina Volcano activity started around $550 \mathrm{kyr}$ and ended about $150 \mathrm{kyr}$ BP (Rouchon et al. 2008). During the first stage of its evolution an alternation of mainly lava and minor pyroclastic deposits were erupted. A succession of highly explosive eruptions and the emplacement of Brown Leucitic Tuff (Luhr and Giannetti 1987) characterized the second stage, which started about $350 \mathrm{kyr}$ BP. The final stages show a decrease in the volcanic activity magnitude and the deposition of Teano pyroclastic deposits (Giordano et al. 1995) and the White Trachythic Tuff (Cole et al. 1992, Giannetti and De Casa 2000).

The Riardo Plain was mostly filled by the volcanic deposits of the Roccamonfina Volcano, which in turn were later covered by the Campanian Ignimbrite, erupted about $33 \mathrm{kyr}$ BP from the Campi Flegrei region (De Vivo et al. 2001) and by the actual alluvial deposits.

A succession of three deposits could be extensively identified in the Riardo Plain, according to the described Roccamonfina Volcano activity stages:

i. lower volcanoclastic deposits in alluvial facies, derived from the weathering of the deposits emplaced during the first stage of the Roccamonfina Volcano evolution;

ii. chaotic, massive and often lithic pyroclastic flow deposits (Brown Leucitic Tuff) with lava fragments in ashy matrix and variable thickness up to $50 \mathrm{~m}$;

iii. upper volcanoclastic alternation of pumices, ash and mudflows in fluvial facies (Teano Pyroclastic deposits) and pumice levels (White Trachytic Tuff).

\section{Hydrogeological setting}

The study area is located in the Campania region, characterized by a typical Mediterranean climate with dry and warm summers and a wet period that occurs during autumn, winter and spring. The monthly rainfall reaches a maximum during November and a minimum in July (Ducci and Trafaglia 2008, Fiorillo 2009). The annual mean rainfall ranging between about $1500 \mathrm{~mm}$ on the Roccamonfina volcano (Regione Campania unpublished report 2013) and about 900 $\mathrm{mm}$ near Riardo town (Ferrarelle unpublished report 2015).

The Riardo Plain is located between two hydrogeological regional units: Roccamonfina Unit toward west and Mount Maggiore Unit toward east and south. The carbonate hydrostructure of Mount Maggiore feeds Triflisco Springs and Pila Springs (total mean discharge about $4.6 \mathrm{~m}^{3} / \mathrm{s}$ ) placed at the southernmost sector of the structure, at an elevation of $30 \mathrm{~m}$ a.s.l. The volcanic hydrostructure of Roccamonfina hosts a regional centrifugal aquifer, which constitutes an open hydrogeological unit towards the surrounding hydrostructures. The Roccamonfina recharge area $\left(351 \mathrm{~km}^{2}\right)$ feeds several springs up to a total discharge of $2.1 \mathrm{~m}^{3} / \mathrm{s}$ (including Savone linear spring of about $1.2 \mathrm{~m}^{3} / \mathrm{s}$ ), and a not well-defined groundwater leakage of about $2 \mathrm{~m}^{3} / \mathrm{s}$ (Boni et al. 1986).

The volcanic and carbonate aquifers are in contact under the alluvial filling deposits of Riardo Plain; the definition of the hydraulic connection is one of the topics of the current research. In the past, the two aquifers naturally fed the Ferrarelle springs. Nowadays, Ferrarelle S.p.a taps water from both aquifers only by means of wells.

Different aquifer levels can be distinguished in the area. Recent hydrogeological researches on the Roccamonfina Volcano (Viaroli et al. 2016) suggested the distinction between the groundwater circulation in the caldera and the basal volcanic aquifer, according to the identification of some perched aquifers, also characterized by different chemical composition.

The basal volcanic multilayer aquifer is recharged from the upper volcano edifice and groundwater centrifugally moves toward the surrounding plains, with water table elevation decreasing up to about $50 \mathrm{~m}$ a.s.l. in the southern portion of the Riardo Plain. The basal fractured-carbonate aquifer, characterized by high secondary porosity, is recharged from both the eastern volcano structure (Capelli et al. 1999, Cuoco et al. 2010) and from the surrounding carbonate ridges (Mazza et al. 2013).

Dolomite and dolomitic limestone of the Mount Maggiore ridge, raised by Rocchetta Fault, seem to play a decisive role in the hydrogeological settings of the Riardo Plain. In fact, the Triassic dolomite presents a lower secondary porosity than the Cretaceous limestone and then it could play the role of local aquitard (Celico et al. 1979, Allocca et al. 2007). It probably continues below the Riardo Plain, lowered by the extensive faults. The dolomitic aquitard could divide the buried carbonate aquifer in two sectors. In the eastern sector of the plain, the piezometric surface was detected at an elevation between 80 and $40 \mathrm{~m}$ a.s.l., about sixty meters lower than volcanic water table elevation (between 140 and $100 \mathrm{~m}$ a.s.l.). On the contrary, in the western sector, the carbonate piezometric surface has the same elevation (between 140 and $60 \mathrm{~m}$ a.s.l.) of the volcanic one (Capelli et al. 1999, Mazza et al. 2013).

In the Riardo Plain, anomalous $\mathrm{CO}_{2}$ degassing areas are aligned in NE-SW direction, according to the direction of the two faults detected on the field on the surrounding carbonate reliefs and deduced by geophysical surveys (Giordano et al. 1995). Mineralized groundwater of the Riardo Plain are supersatured in $\mathrm{CO}_{2}$ and they show bicarbonate-alkali earth facies, in fact the $\mathrm{CO}_{2}$ fluxes are responsible for intense carbonate hydrolysis bringing in solution large amounts of alkali-earth metals. The typical chemical composition derives from water-rocks interactions, both with volcanic and carbonate rocks (Cuoco et al. 2010)

\section{Materials and Methods}

Several hydrogeological surveys were carried out by Hydrogeology Laboratory of Roma Tre University from 1998 to 2015 in the Riardo Plain and in the surrounding hydrostructures, throughout the long-lasting research collaboration with Ferrarelle S.p.a.

Data about location and discharge of the springs, the groundwater depth in wells and the water samples for the chemical analysis were collected during the field surveys.

The springs discharge was measured using a SEBA Hydrometrie M1 mini current meter. The discharge rate of 
minor springs $(<1 \mathrm{~L} / \mathrm{s})$ was measured by volumetric method. Progressive discharge measurements along main streams allowed to quantify the groundwater outflowing in the rivers (linear springs) (Boni et al. 1986). About 120 gauging stations are taken into consideration during the last hydrogeological survey. The discharge measures were always taken at least one week after the last significant rainfall event, in order to exclude the runoff contribution from the assessment of the base flow (groundwater contribution to stream discharge).

Data regarding groundwater depth were measured in agricultural, domestic or in drinking supply wells under static conditions, using phreatimeters or sonic water level meters. About 80 wells were measured during the last survey.

In situ chemical-physical parameters (temperature, $\mathrm{pH}$ and electric conductivity EC with automatic compensation to $20^{\circ} \mathrm{C}$ ) were measured in each monitoring point using portable probes (WTW $\mathrm{pH} /$ cond 340i). A water sample of some monitoring points was collected for major ions chemical analysis in the Riardo Plain, which is the focus of this research.

Groundwater depth was daily measured in two monitoring wells using automatic probes (Schlumberger DIVER) from March 2013 to September 2014. The monitoring wells tap different aquifers, in order to evaluate the relationship between the carbonate and the volcanic aquifers during a long-time monitoring.

Detailed hydrogeological and hydrochemical surveys started in summer 2015 are currently ongoing in the Roccamonfina Caldera. The preliminary results of these surveys are being interpreted.

In addition to the fieldwork, many data from former studies, made available by Ferrarelle S.p.a and Liri Garigliano-Volturno Basin Authority (Corbelli et al. 2008), were collected. All data have been organized in a GIS database, in order facilitate the analysis and better distinguish the different aquifers. Wells used to realize the potentiometric maps (Fig. 4) were selected according to the well bottom elevation and stratigraphic information, in order to reduce wrong correlations between monitoring points tapping different aquifers.

Major ions data of 60 groundwater samples were also examined only in the Riardo Plain (Fig. 5) to validate the conceptual flow model, identifying where the carbonate and the volcanic aquifers are separated and where they are in hydraulic connection.

\section{Results}

The experimental and bibliographic data processing allowed: i) the identification of the portions of the streams fed by groundwater flow (linear springs); ii) the realization of four potentiometric surfaces also according to the linear springs elevations (Fig. 6).

Four linear springs were identified and the discharge rates were reported in the Tab. 1. The main linear spring corresponds to the lower Savone River (S1) at elevations between 95 and $40 \mathrm{~m}$ a.s.l. S1 spring represents the basal level of groundwater flow in the study area with an average discharge of about $210 \mathrm{~L} / \mathrm{s}$ (over the period 1998-2015).

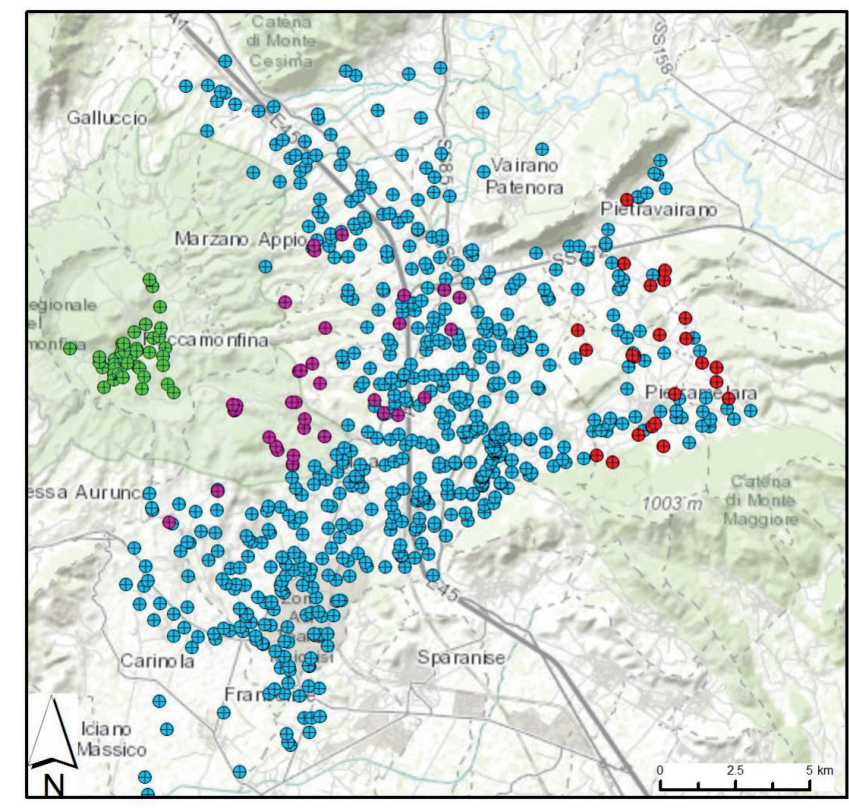

Fig. 4 - Location of the wells used to realize the potentiometric map.

Fig. 4 - Ubicazione dei pozzi utilizzati per la realizzazione della carta piezometrica.

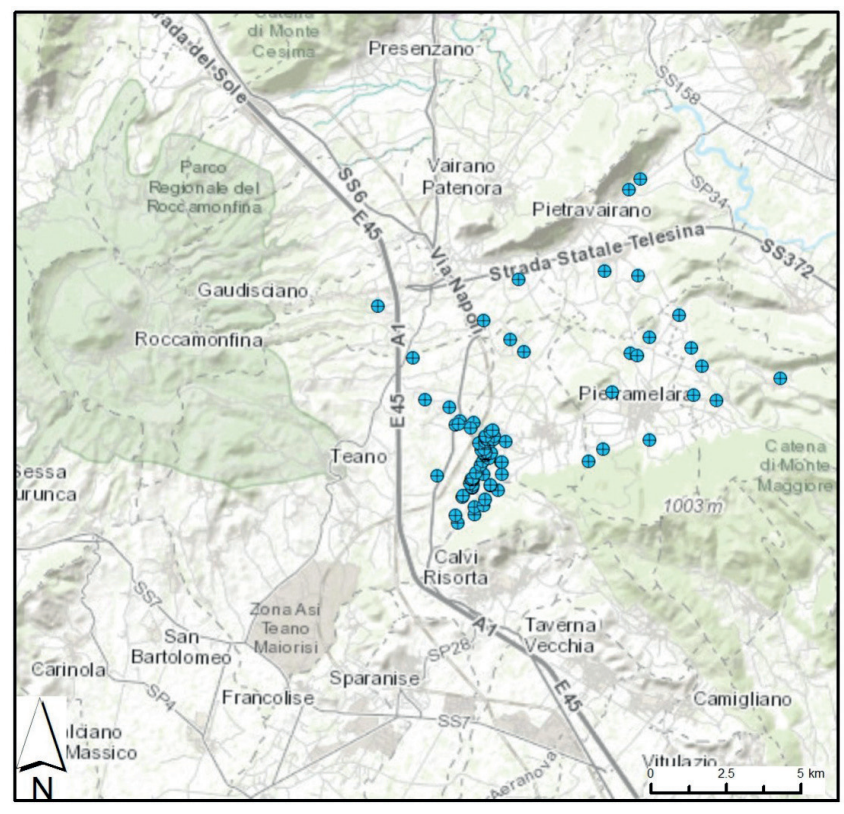

Fig. 5 - Location of sampling wells for the chemical analysis.

Fig. 5 - Punti dei pozzi di campionamento per le analisi chimiche.

The second linear spring was identified in the upper Savone delle Ferriere Stream (S2) within the Roccamonfina Caldera. The linear spring drains the aquifer hosted in the pyroclastic deposits filling the caldera at an elevation between 540 and $350 \mathrm{~m}$ a.s.l., with a mean discharge rate of about $130 \mathrm{~L} / \mathrm{s}$.

The lower portion of the Starze Stream valley corresponds to the $S 3$ linear spring, which drains the volcanic aquifer of the eastern sector of the Riardo Plain at an elevation between 125 and $100 \mathrm{~m}$ a.s.l. 


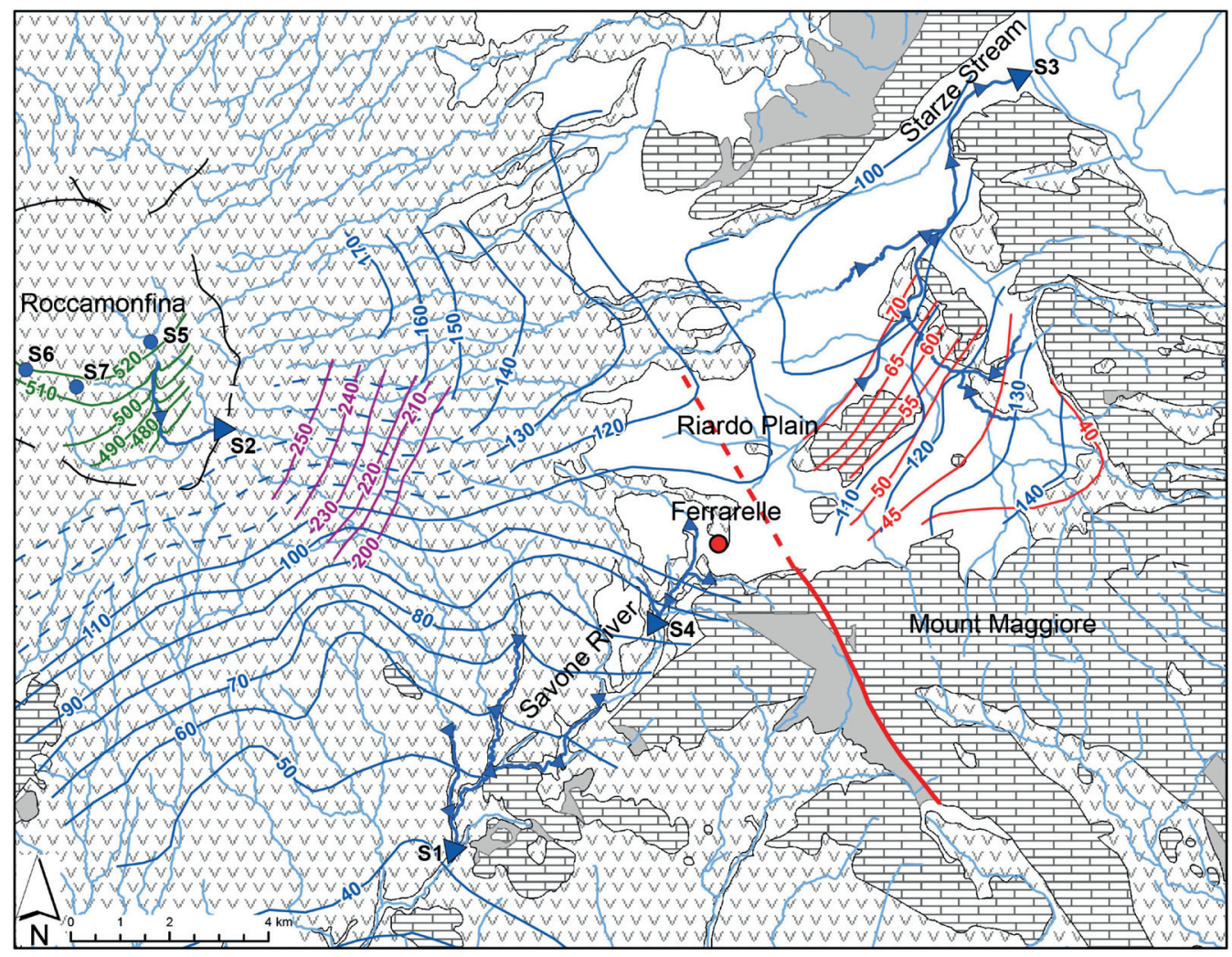

Legend

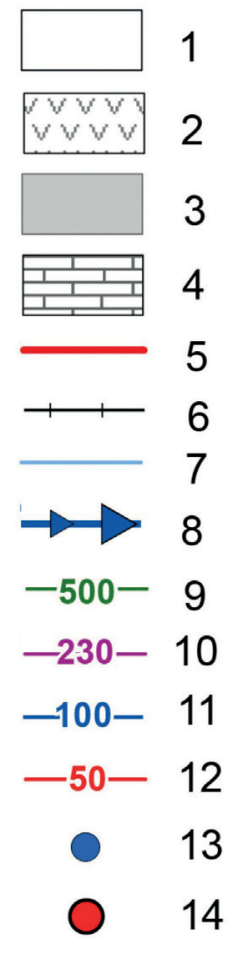

Fig. 6 - Hydrogeological map of the study area. Legend: 1) alluvial deposits; 2) volcanic deposits; 3) Flysch units; 4) limestone and dolomitic limestone; 5) Rocchetta fault; 6) Caldera rim; 7) bydrographic pattern; 8) Linear springs; 9) perched aquifer in the Roccamonfina Caldera; 10) perched aquifer on the eastern flank of the Roccamonfina volcano; 11) basal aquifer; 12) deep carbonate aquifer in the eastern Riardo Plain; 13) main localized springs ( $Q>10 \mathrm{~L} / \mathrm{s}) ; 14)$ Ferrarelle S.p.a. plant.

Fig. 6 - Carta idrogeologica dell'area di studio. Legenda: 1) depositi alluvionali; 2) depositi vulcanici; 3) unità flyschoidi; 4) calcari e calcari dolomitici; 5) faglia di Rocchetta; 6) orlo calderico; 7) reticolo idrografico; 8) sorgenti lineari; 9) acquifero superficiale nella caldera di Roccamonfina; 10) acquifero superficiale sul versante orientale del Vulcano di Roccamonfina; 11) acquifero basale; 12) acquifero carbonatico profondo nella Piana di Riardo orientale; 13) principali sorgenti puntuali $(\mathrm{Q}>10 \mathrm{~L} / \mathrm{s}) ; 14)$ stabilimento Ferrarelle S.p.a.

Tab. 1 - Average discharge rate and elevation of the main springs (period 1998-2015). Tab. 1 - Portata media e quota delle principali sorgenti (nel periodo 1998-2015).

\begin{tabular}{|c|c|c|}
\hline Spring code & $\begin{array}{c}\text { Elevation } \\
\text { m a.s.l. }\end{array}$ & $\begin{array}{c}\text { Discharge rate } \\
\text { L/s }\end{array}$ \\
\hline S1 & $90-40$ & 210 \\
\hline S2 & $540-350$ & 130 \\
\hline S3 & $125-100$ & 130 \\
\hline S4 & $120-75$ & 110 \\
\hline S5 & $95-50$ & 90 \\
\hline S6 & $90-45$ & 40 \\
\hline S7 & 550 & 15 \\
\hline S8 & 590 & 15 \\
\hline S9 & 580 & 10 \\
\hline
\end{tabular}

The S4 linear spring, with average discharge about $110 \mathrm{~L} / \mathrm{s}$, corresponds to the surplus of the original natural spring area, now exploited by Ferrarelle s.p.a.

Some small local perennial springs were also detected in the Roccamonfina Caldera at elevation higher than $550 \mathrm{~m}$ a.s.l. Only three of them have a discharge rate higher than $10 \mathrm{~L} / \mathrm{s}$ (S5, S6 and S7).

Four water tables maps were realized using both experimental and former hydrogeological data. The highest water table (between 520 and $480 \mathrm{~m}$ a.s.l.) was detected in 43 monitoring wells inside the caldera, and it feeds the Roccamonfina caldera linear spring (S2). Another water table was distinguished along the eastern volcano slope at an elevation between 250 and $200 \mathrm{~m}$ a.s.l. in 30 monitoring points. It corresponds to one of the many groundwater perched flows of the multilayer volcanic aquifer.

The main basal groundwater direction moves from the volcano toward the southern and the western sector of the Riardo Plain with elevations between 170 and $40 \mathrm{~m}$ a.s.l. and a mean hydraulic gradient of about $1.5 \%$. This aquifer, detected in more than 500 wells, feeds both S1 and S4 linear springs with total discharge about $470 \mathrm{~L} / \mathrm{s}$. A groundwater divide separates this flow path from one feeding the $\mathrm{S} 3$ linear spring $(130 \mathrm{~L} / \mathrm{s})$ in of eastern sector of the Riardo Plain. In the same sector another lower (between 70 and $40 \mathrm{~m}$ a.s.l.) and contrariwise (SE direction) flow path was identified in the carbonate deposits in 34 monitoring wells.

The major ions data of the 60 groundwater samples, plotted on the Ludwig-Langelier diagram (Fig. 7), show that the most represented water type in the study area is $\mathrm{Ca}-\mathrm{Mg}\left(\mathrm{HCO}_{3}\right)_{2}$ whereas, only a small number of collected samples were $\mathrm{Na}$ $\mathrm{K}\left(\mathrm{HCO}_{3}\right)$. The preponderance of the $\mathrm{Ca}-\mathrm{Mg}\left(\mathrm{HCO}_{3}\right)_{2}$ water type agrees with both the mineralogical composition of 


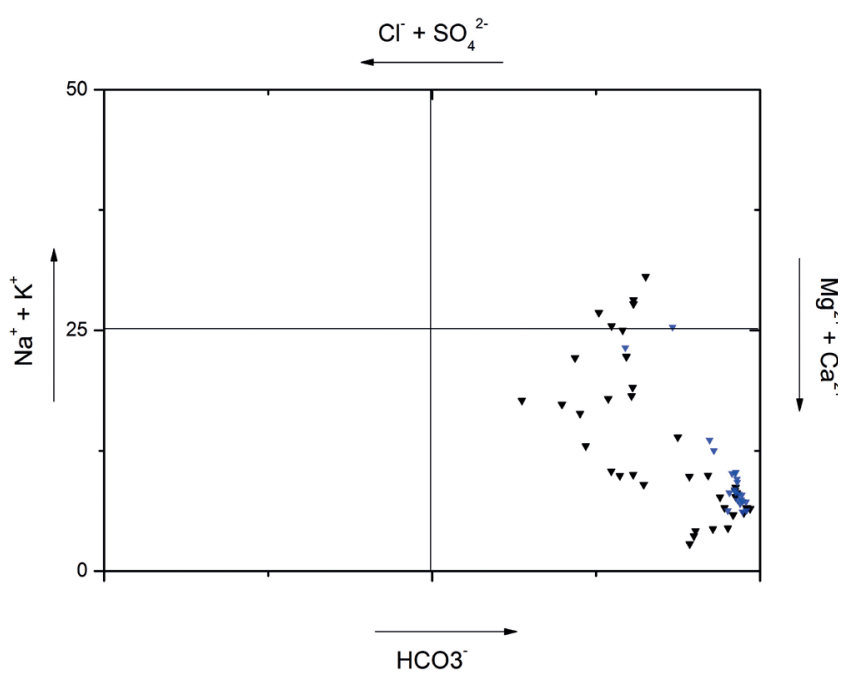

Fig. 7 - Ludwig-Langelier diagram of the sampled points reported in Fig. 5. The blue triangles correspond to Ferrarelle groundwater samples.

Fig. 7 - Diagramma Ludwig-Langelier dei punti campionati riportati in Fig. 5. I triangoli blu corrispondono ai campioni d'acqua Ferrarelle.

carbonate aquifer and mineralogical features of the Roman magmatic province, of which Roccamonfina volcano is the most southern part (Le Bas et al. 1986, Rouchon et al. 2008).

\section{Discussion}

The present hydrogeological survey and the outcomes of Mazza et al. (2013) allowed the definition of a more detailed hydrogeological conceptual model than the one described in Capelli et al. (1999).

In the study area groundwater flow moves from the eastern slope of Roccamofina Volcano toward the Riardo Plain feeding several springs (including the Ferrarelle mineral water system) for a total discharge of about $580 \mathrm{~L} / \mathrm{s}$. The groundwater circulation is divided in two different basins by a groundwater divide with NNW-SSE direction, which partially corresponds to the hydrographic watershed. The weak relief of the ground morphology, which create the local hydrographic watershed at the base of the Mount Maggiore slope, near Riardo town, could be related to the longitudinal extension of the Rocchetta horst, gradually lowered under the deposits of the Riardo Plain.

The eastern slope of Roccamonfina Volcano is the recharge area of the entire western sector of the Riardo Plain, but also it recharges the northwestern area of the eastern sector of the Riardo Plain according to the water table elevation map in Fig. 6. On the contrary, the southeastern sector of the Riardo Plain is recharged only by local zenithal infiltration.

The different elevations of the water tables along the Roccamonfina slope indicate that only a minor rate of the infiltrated water through the upper volcano slope feeds the basal groundwater flow. Several perched aquifers were identified according to the latest results of a more detailed hydrogeological survey of the Roccamonfina Caldera.

Only few deep wells reach the carbonate aquifer. In the western sector, the wells were drilled in a limited area that corresponds to the Ferrarelle S.p.a. mining claim. The wells were realized in order to exploit only the carbonate aquifer, screening the portion that corresponds to the limestone units. Nevertheless, in this sector of the Riardo Plain the water table elevation of the volcanic and carbonate aquifers is the same, as evidence of the hydraulic continuity between the aquifers as already supposed by Capelli et al. (1999) and later supported by Cuoco et al. (2010) on the basis of geochemical analysis.

On the contrary, significant differences in the groundwater table elevations of the volcanic and carbonate aquifers could be distinguished in the eastern sector of the Riardo Plain.

So far, the assumptions about the nature of the aquiclude separating the two aquifers have not yet confirmed (lacustrine level, massive and lithic pyroclastic flow deposits or flysch units). These observations should confirm the key role of the tectonic system of the Rocchetta Fault to the hydrogeological setting of western sector of the plain, where Ferrerelle well field is located. The extension of the Rocchetta graben under the volcanoclastic deposits of the Riardo Plain seems to influence the groundwater divide of volcanic aquifer, as explained in the previous paragraph. Furthermore, the fault raises the Triassic Dolomite (characterized by lower hydraulic conductivity) at a higher elevation compared to the carbonate saturation level, acting the role of the local aquitard also below the Riardo Plain. The aquitard behaves like a hydraulic barrier in the deep carbonate groundwater flow. In fact, only the eastern portion of the Mount Maggiore recharges the Pila and Trifilisco springs (30 $\mathrm{m}$ a.s.1.); whereas, in the western sector the carbonate water table remains at a higher elevation than in the eastern sector, in hydraulic equilibrium with the overhead volcanic aquifer.

The hydraulic continuity between the volcanic and carbonate aquifers has been confirmed by means of daily data of water table elevation detected in two monitoring wells realized by Ferrarelle S.p.a. (Fig. 8). In spite of the different location of the screens (the Pzlb well screen is located in the volcanic aquifer whereas Pzla well taps the carbonate aquifer) the two water table fluctuations are very similar. It is worth to note annual trend of the groundwater level matches the variation of the recharge during the hydrologic year: higher groundwater elevations were detected during the spring (wet season) whereas the minimum annual groundwater level was measured in summer during the dry season. The carbonate aquifer has a groundwater level some decimeters higher than the volcanic one, suggesting an uprising of the deeper aquifer through the volcanic deposits. The difference between the groundwater levels is related to the different permeability of the fractured limestone compared to the volcanic deposits.

Moreover, the Rocchetta fault seems to limit eastward the gas vents area. The gas emission points are lined up in NESW direction in the southern sector of Riardo Plain (Giordano et al. 1995), just where Ferrarelle S.p.a. factory is located.

The results of chemical data (Fig. 9) interpretation seem to prove the conceptual hydrogeological model previously described. The analyzed waters may be divided into three main groups, according to the proposed groundwater flow directions. 


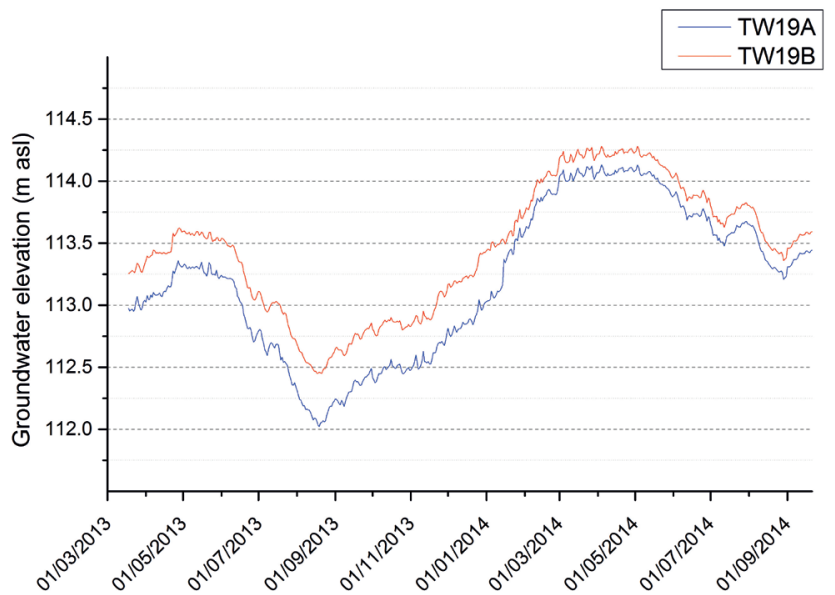

Fig. 8 - Mean daily groundwater elevation of the carbonate aquifer (red line) measured in Pz1 a monitoring well and the elevation of the volcanic aquifer (blue line) measured in $P z 1 b$ monitoring well.

Fig. 8 - Quota media giornaliera della falda carbonatica (linea rossa) misurata nel piezometro Pzla e della falda vulcanica (linea blue) misurata nel piezometero Pz1b.

The groundwater of the carbonate aquifers (red lines in Fig. 9A and 9B) shows two different compositions according to the hydraulic separation made by the Rocchetta Fault aquitard/aquiclude. The western carbonate aquifer shows higher alkaline $\left(\mathrm{Na}^{+}+\mathrm{K}^{+}\right)$ion content as a consequence of the mixing between the carbonate and the volcanic aquifers. Furthermore, the western carbonate aquifer shows a $\mathrm{Ca}^{2+}$ and $\mathrm{HCO}_{3}{ }^{-}$enrichment due to the $\mathrm{CO}_{2}$ upraising. All carbonate water were collected in deep wells located only in the southern zone of the western sector, where the limestone roof reaches

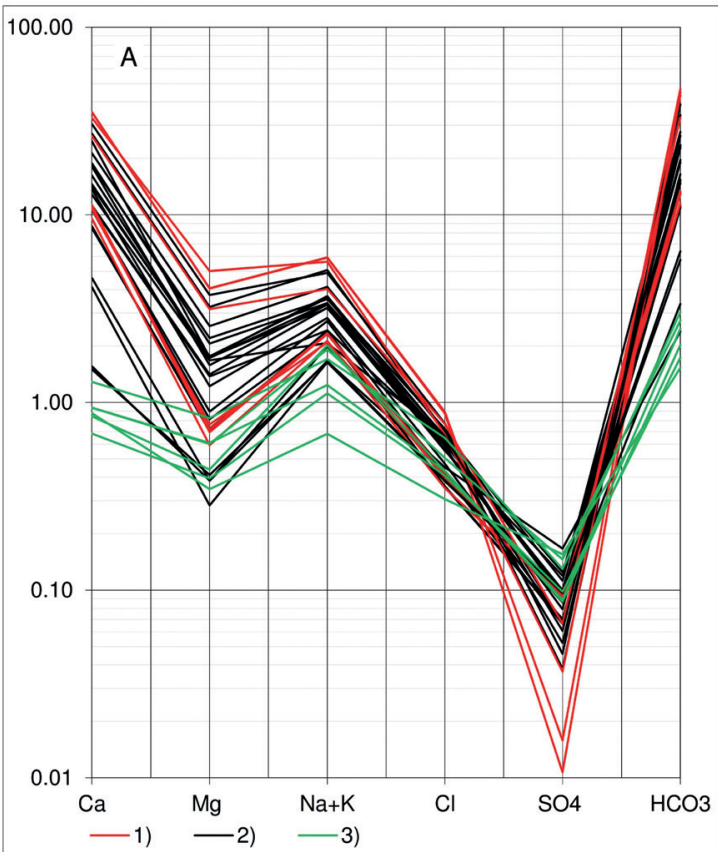

a maximum depth of $200 \mathrm{~m}$ b.g.l. and where the gas vents area is located. In the northern zone of the western sector, the limestones are located at several hundred $\mathrm{m}$ b.g.l. (Capuano et al. 1992) therefore, there is no information about the carbonate groundwater flow path in this area.

The chemical results of the volcanic water confirm the mixing of the carbonate and the volcanic aquifers in the southwestern zone, where Ferrarelle S.p.a. well field is located. In fact, the waters of the two aquifers (black and red lines in Fig. 9A) do not show significant chemical differences.

The chemical composition of volcanic water, collected in the northwestern zone of the Riardo Plain (green lines in Fig. 9A), is different from the other volcanic samples. In fact, $\mathrm{Na}-\mathrm{K}\left(\mathrm{HCO}_{3}\right)_{2}$ water are only present in this sector, pointing out the exclusive volcanic origin of the aquifer, recharged from the infiltrated waters through the eastern slope of the Roccamonfina Volcano.

The same $\mathrm{Na}-\mathrm{K}\left(\mathrm{HCO}_{3}\right)_{2}$ waters were also collected in the NW zone eastern sector of Riardo Plain (green lines in Fig. 9B), confirming that this sector is fed by the same eastern slope of Roccamonfina volcano that recharges the western sector aquifers.

The SE groundwater samples of the eastern Riardo Plain (black lines in Fig. 9B) request a detailed reading. This groundwater circulation seems to be affect by a slight carbonate water mixing, probably due to local zenithal recharge in both volcanoclastic deposits and local debris cone deposits (about $2 \mathrm{~km}^{2}$ ) along the edge of the Mount Maggiore. Additional analyses are necessary to develop this matter

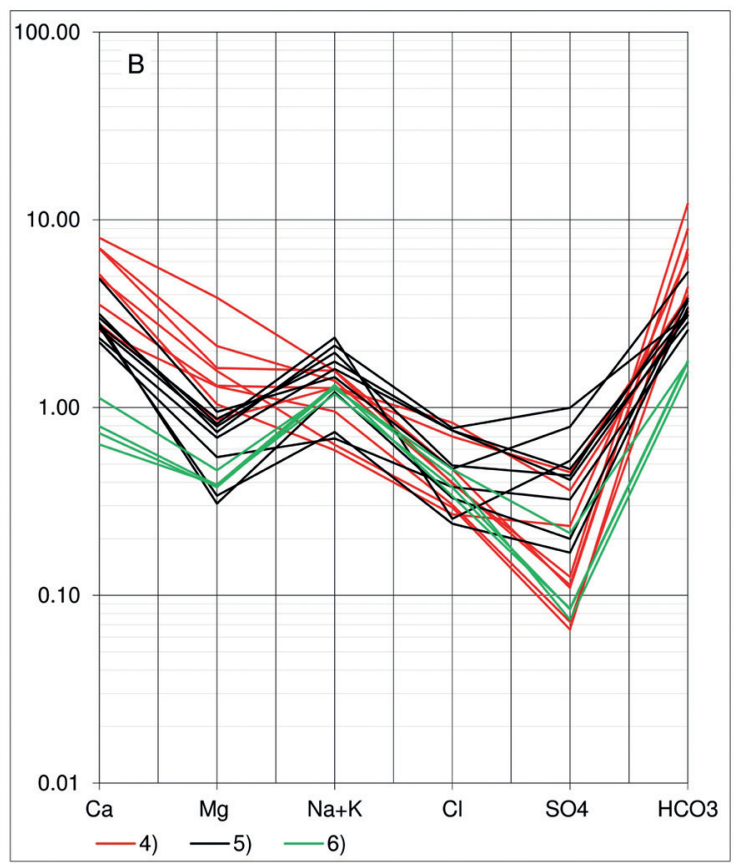

Fig. 9 - Shoeller diagrams of main elements (meq/L) of the groundwater sampled in the Riardo Plain. A) (Western sector): 1) carbonate aquifer (Ferrarelle wells); 2) SW volcanic aquifer (Ferrarelle wells); 3) NW volcanic aquifer. B) (Eastern sector): 4) carbonate aquifer; 5) SE volcanic aquifer; 6) volcanic aquifer (NW zone).

Fig. 9 - Diagrammi di Schoeller degli elementi principali (meq/L) degli acquiferi della Piana di Riardo. A) (settore occidentale): 1) acquifero carbonatico (Pozzi Ferrarelle); 2) acquifero vulcanico nel settore sud occidentale (Pozzi Ferrarelle); 3) acquifero vulcanico nel settore nord occidentale. B) (settore orientale): 4) acquifero carbonatico; 5) acquifero vulcanico del settore sud orientale; 6) acquifero vulcanico nella zona nord occidentale. 


\section{Conclusions}

The Ferrarelle S.p.a. mineral water presents peculiar chemical composition and natural sparkling characteristic due to the synergy of two hydrogeological features: the carbonate and volcanic groundwater mixing; the natural presence of $\mathrm{CO}_{2}$ in the aquifers.

The link between the geological setting, the aquifer geometry and chemical feature of groundwater resource of Riardo Plain has been the topic of this study. The results derived from the processing and elaboration of a large amount of data collected during a twenty years scientific collaboration between Roma Tre University and Ferrarelle S.p.a.

In brief, two sectors are distinguished in the Riardo Plain hydrostructural setting, separate by the Rocchetta fault.

The western sector is characterized by the mixing of the carbonate and the volcanic aquifers, which show the same elevation and fluctuation of groundwater table. The main recharge area of both aquifers is located in the eastern slope of Roccamonfina Volcano. The western sector of the Riardo Plain can be divided in two sub-zones: southern zone with diffuse $\mathrm{CO}_{2}$ vents, and the northern zone where significant gas emissions are not present.

In the eastern sector, no significant gas emissions were detected and two overlapping aquifers are recognized. The lower aquifer is hosted in the carbonate deposits, buried below the volcanoclastic sediments and its recharge area has not been defined yet. In the upper volcanoclastic aquifer, two different flow paths could be distinguished, separated by a NE-SW groundwater divide. The NW circulation is fed by east slope of Roccamonfina volcano, which also recharges the western aquifers; on the contrary, the SE circulation seems to be exclusively recharged by zenithal infiltration in the local volcanoclastic deposits.

One of the main goals of the long term studies was the statement of the role of the Rocchetta Fault extensional tectonic system, in the complex structural settings of the Riardo Plain, the carbonate ridge of Mount Maggiore and the Roccamonfina Volcano. The Mount Maggiore horst, westward bounded by the Rocchetta Fault, seems to influence the groundwater flow paths of both the volcanic and the carbonate aquifers. The fault raises the Triassic Dolomite (characterized by lower hydraulic conductivity) up to the carbonate saturation level, realizing a local aquitard also below the Riardo Plain. This aquitard behaves like a hydraulic barrier toward the deep carbonate aquifer and prevents to the western carbonate aquifer the recharge of the Pila and Triflisco springs $(30 \mathrm{~m}$ a.s.l.). Therefore, in the western sector the carbonate water table remains at a higher elevation than in eastern sector and the saturation level reaching the hydraulic equilibrium with the water table of overhead volcanic aquifer. This specific hydrostructural setting supports the water mixing condition between carbonate and volcanic aquifer just where the $\mathrm{CO}_{2}$ uprising is more active.

Acknowledgment: the authors thank Francesca Lotti for the prompt and precious review and suggestions to improve the manuscript.

\section{REFERENCES}

Allocca V, Celico F, Celico P, De Vita P, Fabbrocino S, Mattia C, Monacelli G, Musilli I, Piscopo V, Scalise AR, Summa G, Tranfaglia G (2007) Note illustrative della Carta idrogeologica dell'Italia Meridionale "Explanatory notes of the Hydrogeological Map of southern Italy". Istituto Poligrafico e Zecca dello Stato, Rome.

Boni C, Bono, Capelli G (1986) Schema idrogeologico dell'Italia centrale "Hydrogeological scheme of Central Italy". Mem Soc Geol It 35(2):991-1012.

Bono P, Boni C (2001) Mineral waters in Italy. In: La Moreaux PE, Tanner JT (eds.), Springs and bottled waters of the world. SpringerVerlag, Berlin. pp 183-189.

Capelli G, Mazza R, Trigari A, Catalani F (1999) Le risorse idriche sotterranee strategiche nel distretto vulcanico di Roccamonfina (Campania nord-occidentale) "The strategic groundwater resources in the Roccamonfina volcanic district (North-west Campania Region)". Pitagora Editrice, Bologna.

Capuano P, Continisio R, Gasparini P (1992) Structural setting of a typical alkali-potassic volcano: Roccamonfina, southern Italy. Journal of Volcanology and Geothermal Research 53:355-369.

Celico P (1983) Idrogeologia dei massicci carbonatici, delle piane quaternarie e delle aree vulcaniche dell'Italia centro-meridionale " $H y$ drogeology of the carbonatic massif, quaternary plains and volcanic areas of central and southern Italy". Cassa per il Mezzogiorno, Rome.

Celico P, Civita M, Corniello A (1977) Idrogeologia del margine nordorientale della conca campana (Massicci dei Tifatini e del Monte Maggiore) "Hydrogeology of the north-western edge of the campanian hollow (Tifatini Massifs and Mount Maggiore)". Mem Note Ist Geol Appl 13:1-29.

Celico P, De Gennaro M, Ghiara MR, Stanzione D (1979) Le sorgenti termominerali della Valle del Sele (Salerno): indagini strutturali, idrogeologiche e geochimiche "The thermo-mineral springs of Sele Valley (Salerno): hydrogeological, geochemical and structural surveys". Rendiconti Società Italiana di Mineralogia e Petrologia 35(1):389-409.

Chiappini M, Ferraccioli F, Bosi V, Bozzo E, Caneva G, Funiciello R (1998) An experimental aeromagnetic survey in the Volturno valley area (South-Eastern Latium). Annali di Geofisica 41(3):469-476.

Civitelli G, Brandano M (2005). Atlante delle litofacies e modello deposizionale dei Calcari a Briozoi e Litotamni nella Piattaforma carbonatica laziale-abruzzese "Atlas of the lithofacies and the depositional model of Calcari a Briozoi e Litotamni formation in the Lazio-Abruzzi carbonatic shelf". Boll Soc Geol It 124:611-643.

Cole PD, Guest JE, Duncan AM, Chester DK, Bianchi R (1992) Post collapse volcanic history of calderas on a composite volcano: an example from Roccamonfina volcano, southern Italy. Bullettin of Volcanology 54:253-266.

Corbelli V, Pagliaro S, Pesce S, Forni V (2008) Complesso vulcanico del Roccamonfina. Stima dei prelievi e valutazione del depauperamento della risorsa idrica "Roccamonfina volcanic complex. Evaluation of the withdrawals and evaluation of the depletion of the groundwater resource". Autorità di Bacino dei fiumi Liri-Garigliano e Volturno, Naples.

Cuoco E, Paolucci V, Vaselli O, Porreda RJ, Tedesco D (2016) Groundwater dynamic equilibrium in the ferrarelle multi-layer aquifer systems. Evidences from fluids geochemistry. Rend Online Soc Geol It 39(Suppl.1):108. doi:10.3301/ROL.2016.63

Cuoco E, Verrengia G, De Francesco S, Tedesco D (2010) Hydrogeochemistry of Roccamonfina volcano (Southern Italy). Environ Earth Science 61:525-538. doi:10.1007/s12665-009-0363-3

D’Argenio B, Pescatore T (1962) Stratigrafia del Mesozoico nel gruppo del monte Maggiore (Caserta) "Stratigraphy of the mesozoic units of the Mount Maggiore group (Caserta)". Bollettino della Società dei Naturalisti in Napoli 71:55-61. 
D’Argenio B, Pescatore T (1963) La tettonica del gruppo del Monte Maggiore "The tectonic of the Mount Maggiore group". Bollettino della Società dei Naturalisti in Napoli 72:1-12.

De Vivo B, Rolandi G, Gans PB, Calvert A, Bohrson WA, Spera FJ, Belkin HE (2001) New constraints on the pyroclastic eruptive history of the Campanian volcanic Plain (Italy). Miner Petrol 73(13):47-65.

Dinelli E, Lima A, De Vivo B, Albanese S, Cicchella D, Valera P (2010) Hydrogeochemical analysis on Italian bottled mineral waters: effects of geology. Journal of Geochemical Exploration 107:317-335. doi:10.1016/j.gexplo.2010.06.004

Ducci D, Trafaglia G (2008) Effects of climate change on groundwater resources in Campania (southern Italy). Climate Change and Groundwater 288:25-38.

Fiorillo F (2009) Spring hydrographs as indicators of droughts in a karst environment. Journal of Hydrology 373:290-301.

Giannetti B, De Casa G (2000) Stratigraphy, chronology and sedimentology of ignimbrites from the white trachytic tuff, Roccamonfina Volcano, Italy. J Volcanol Geotherm Res 96:243-295.

Giordano G, Naso G, Scrocca D, Funiciello R, Catalani F (1995) Processi di estensione e circolazione di fluidi a bassa termalità nella Piana di Riardo (Caserta, Appennino centro-meridionale) "Extensional processes and underground circolation of low thermal fluids in the Riardo Plain (Caserta, central-southern Appennine". Boll Soc Geol It 144:361-371.

Imperato M, Dadà G, Naimo D, Oster H, Paolucci V, Sacchi E (2016) Hydrogeological and hydrochemical features of a hyghly valuable mineral water basin: Ferrarelle, Southern Italy. Rend. Online Soc Geol It 39(Suppl.1):106. doi:10.3301/ROL.2016.63.

Le Bas MJ, Le Maitre RW, Streckeisen A, Zanettin (1986) A chemical classification of volcanic rocks based on the total alkali - silica diagram. Journal of Petrology 27:745-750.

Luhr JF, Giannetti B (1987) The Brown Leucitic Tuff of Roccamonfina volcano (Roman Region, Italy). Contrib Miner Petrol 95:420-436.

Maréchal JG, Lachassagne P, Ladouche B, Dewandel B, Lanini S, Le Strat P, Petelet-Giraud E (2013) Structure and hydrogeochemical functioning of a sparkling natural mineral water system determined using a multidisciplinary approach: a case study from southern France. Hydrogeology Journal. doi:10.1007/s10040-013-1073-1
Mazza R, Pietrosante A, Taviani S, Viaroli S (2013) A preliminary understanding of groundwater exchanges between the Riardo Plain and Mount Maggiore ridge (Campania. Italy). Rend Online Soc Geol It 24:207-209.

Mazza R, Pietrosante A, Taviani S, Viaroli S, Paolucci V (2016) "Ferrarelle" natural mineral water system (Riardo plain - Italy): a multidisciplinary approach in support of groundwater budget calculation. Rend Online Soc Geol It 39(Suppl.1):208. doi:10.3301/ ROL.2016.63

Rouchon V, Gillot PY, Quidelleur X, Chiesa S, Floris B (2008) Temporal evolution of the Roccamonfina volcanic complex (Pleistocene), Central Italy. Journal of Volcanology and Geothermal Research 177:500-514. doi:10.1016/j.jvolgeores.2008.07.016

Sacchi E, Cuoco E, Imperato M, Paolucci V, Tedesco D, Vannucci R (2016) Tracing $\mathrm{CO}_{2}$-water-rock interaction and groundwater circulation with geochemical and isotopic tools: the Riardo basin (CE province, Southern Italy). Rend Online Soc Geol It 39(Suppl.1):735. doi:10.3301/ROL.2016.63

Sahuquillo A (1985) Groundwater in water resources planning: conjunctive use. Water International 10(2):57-63. doi: $10.1080 / 02508068508686308$

Servizio Geologico d'Italia (1966) Carta geologica d'Italia scala 1:100.000, foglio 172 - Caserta "Geological map of Italy at 1:100.000 scale, sheet number 172 - Caserta”. Servizio Geologico d'Italia, Rome.

Servizio Geologico d'Italia (1971) Carta geologica d'Italia scala 1:100.000, foglio 161 - Isernia "Geological map of Italy at 1:100.000 scale, sheet number 161 - Isernia”. Servizio Geologico d'Italia, Rome.

Van der Aa NGFM (2003) Classification of mineral water types and comparison with drinking water standards. Environmental Geology 44:554-563. doi:10.1007/s00254-003-0791-4

Viaroli S, Cuoco E, Mazza R, Tedesco D (2016) Dynamics of natural contamination by aluminium and iron rich colloids in the volcanic aquifers of central Italy. Environmental Science and Pollution Research. doi:10.1007/s11356-016-7198-8

Zuurdeeg BW, van der Weiden MJJ (1985) Geochemical aspects of European bottled water. Theophrastus Publ., Athens. 